\title{
KEANEKARAGAMAN TUMBUHAN HERBA DI TAMAN WISATA ALAM BAUMATA DESA BAUMATA KECAMATAN TAEBENU KABUPATEN KUPANG
}

\author{
Arnold Ch. Hendrik, Noryati Kristiana Duy \\ Correspondent author : Arnold_hendrik@yahoo.co.id \\ Program Studi Pendidikan Biologi, Fakultas Keguruan Dan Ilmu Pendidikan, Universitas Kristen \\ Artha Wacana Kupang
}

\begin{abstract}
ABSTRAK
Taman Wiasata Alam Baumata (TWA) adalah salah satu tempat wisata alam yang berada di Desa Baumata Kecamatan Taebenu terletak $16 \mathrm{Km}$ dari Kota Kupang, TWA Baumata adalah hutan hujan tropik dataran rendah dengan berbagai macam flora dan fauna. Herba adalah tumbuhan pendek dengan tinggi 0,32 meter dan berbatang basah karena banyak mengandung air. Herba juga merupakan tumbuhan tidak berkayu yang tersebar dalam bentuk kelompok individu atau soliter pada berbagai kondisi habitat seperti tanah yang lembab atau berair, tanah yang kering, batu-batuan dan habitat dengan naungan yang rapat. Metode yang di pakai dalam penelitian ini adalah metode kombinasi transek bergaris dan metode kuadran di pilinnya 4 stasiun dalam penelitian ini yaitu stasiun didekat mata air, stasiun rerumputan/semak, stasiun tegakan pohon dan stasiun bebatuan yang di angap mampu untuk mewakili lokasi penelitian. Berdasarkan hasil penelitian yang dilakukan di Taman Wisata Alam Baumata, desa Baumata kecamatan Taebenu, terdapat 7 famili dan8 spesies tanaman Herba yaitu famili Asteraceae yang terdiri dari spesies Syenedrella nodiflora L, Bindes pilosa L sedangkan famili lainya hanya memiliki 1 spesies yaitu famili Amaranthaceae yaituAmaranthus viridis $L$, famili Portulaceae yaitu Portulaca oleraceae L, famili Euphorbiaceae yaitu Euphorbia hirta L, famili polypodiaceae yaitu Pityrograma colemelanus L, famili Costaceae yaitu Costus spesiosus Smith, dan famili Araceae yaitu Homalomena occulta L, Amarathus viridis L, Portulaca oleraceae L, Euphorbia hirta L, Pityrogramma colemelanus L, Syenedrella nodiflora L, Costus spesiosus Smith, Bindens pilosaL, Homalomena occultaL, dengantotalsemua individuberjumlah 329 Individu. Dengan nilai indeks keanekaragaman yang diperoleh pada semua stasiun adalah keanekragaman sedang.
\end{abstract}

Kata kunci : Taman Wisata Alam Baumata, Tanaman Herba, Indeks Keanekaragaman

ABSTRACT
Wiasata Park Natural Baumata (TWA) is wrong one the place tour natural that is located in Village Baumata sub-district Taebenu located $16 \mathrm{Km}$ from Kota Kupang, TWA Baumata is Forest rain tropics plain low with various kinds of flora and fauna. Herbs is plant short with height of $0,3-2$ meters and trunked wet because many contains water. $\mathrm{H}$ erba too is plant not woody spread in form group individual or solitary on various habitat conditions such as moist soil or aqueous, dry soil, rocks and habitat with dense shade. The method in use it in research this is method combination transect striped and method quadrant in choose 4 stations in research this that is station near springs, station grass / bush, station stand tree and station rocks that in angap able to for represent location research. Based on the results research conducted in Taman Wisata Natural Baumata, village Baumata sub-district Taebenu, there are 7 families and 8 species plant Herbs that is family Asteraceae which consists from species Syenedrella nodiflora L, Bindes whereas pilosa L family others only has 1 species that is family A maranthaceae namely Amara $n$ thus viridis $L$, family Portulaceae that is Portulaca oleraceae L, family Euphorbia ceae that is Euphorbia hirta L , family polypodiaceae that is Pityrograma colemelanus L, family Costaceae that is Costus Smith's spesiosus, and family Araceae that is Homalomena L occulta, Amarathus viridis L , Portulaca oleraceae L, Euphorbia hirta L , Pityrogramma colemelanus L, Syenedrella nodiflora L , Costus Smith's spesiosus, Binde $n$ s pilosa L , Homalomena occulta L, dengan total semua individuals totaled 329 The individual. With value index keanekarag safety found on all station is diversity being.

Keywords: Baumata Nature Park, Herbaceous Plants, Diversity Index 


\section{Indigenous Biologi \\ Jurnal pendidikan dan Sains Biologi \\ Volume 1(3) 2018}

\section{PENDAHULUAN}

Hutan adalah habitat bagi tumbuhan-tumbuhan yang beranekaragam. Habitat hutan terkait erat dengan makluk hidup yang ada didalamnya. Hal tersebut disebabkan oleh habitat hutan memberikan asosiasi antara satu dengan lainya seperti jaring-jaring makanan bagi hewan dan tumbuhan, tempat perlindungan flora dan fauna serta menjaga keseimbangan sistem ekologi hutan (Agustina,2010). Keanekaragaman di hutan tropis tidak hanya terbatas pada jenis tumbuhan berkayu atau menahun, namun juga di tumbuhi oleh beranekaragam tumbuhan bawah yang memiliki keanekaragaman jenis yang tinggi. Menurut Ewusie (1990), tumbuhan bawah adalah tumbuhan yang terdiri dari tumbuhan bawah selain pepohonan, misalnya rumput, herba, dan semak belukar atau perdu, serta paku-pakuan.

Herba adalah tumbuhan pendek dengan tinggi 0,3-2 meter dan berbatang basah karena banyak mengandung air. Herba juga merupakan tumbuhan tidak berkayu yang tersebar dalam bentuk kelompok individu atau soliter pada berbagai kondisi habitat seperti tanah yang lembab atau berair, tanah yang kering, batu-batuan dan habitat dengan naungan yang rapat.Herba merupakan salah satu jenis tumbuhan penyusun hutan yang ukurannya jauh lebih kecil jika dibandingkan dengan semak ataupun pohon yang batangnya basah dan tidak berkayu (Nadakuvaren dan McCracken, 1985). Herba memiliki daya saing yang kuat dan adaptasi yang tinggi terhadap tumbuhan disekitarnya (seperti semak, perdu, bahkan pohon).

Taman Wiasata Alam Baumata (TWA) adalah salah satu tempat wisata alam yang berada di Desa Baumata Kecamatan Taebenu terletak $16 \mathrm{Km}$ dari Kota Kupang, TWA Baumata adalah hutan hujan tropik dataran rendah. Berbagai macam flora penyusunnya antara lain: serangan (Castanopsis argentea BI), pakis gelar/paku tiang (Cyathea Molucana R.Br), waru gunung (Hibiscus macrophylus Roxb), kantil (Michelia champaca.L), sedangkan Fauna penyusun TWA Baumata adalah jenis Kijang (Muntiacus muntjak Zimmerman), babi hutan (Sus scrova L), trenggiling (Manis javanicus Desmaresut), luwak (Lariscus insignis Pallas), alap-alap (Accipitridae Temm), tulung tumpuk (Megalaima javensis muller), rangkong (Bucerotidae L), prenjak (Prinia subflava Hors feid), gelatik gunung (Padda orryzivora L), dederuk (Streptopelia $s p$ ). Perkembangan ekosistem pada kawasan ini dijaga untuk tumbuh secara alami tanpa adanya campur tangan manusia. Namun, karena kurangnya pemahaman dan kesadaran dari sebagian warga, kerusakan akibat eksploitasi jenis penyusun komunitasnya pun tak dapat dihindari. Adanya gangguan di kawasan TWA Baumata ini akan berpengaruh terhadap kelestarian hutan tersebut, terutama komunitas biotik penyusunnya seperti tumbuhan herba.

Dipilihnya tumbuhan Herba sebagai objek penelitian ini, selain sebagai salah satu penyusun vegetasi di kawasan TWABaumata juga mempunyai manfaat antara lain sebagai bahan makanandan obat-obatan dan juga menjaga keseimbangan ekosistem, memperkuat struktur tanah hutan, membantu menahan jatuhnya air secara langsung, dan menghambat atau mencegah erosi yang berlangsung secara cepat. Tumbuhan ini dapat menghalangi jatuhnya air hujan secara langsung ke permukaan tanah dan mendorong perkembangan biota tanah yang dapat memperbaiki sifat fisik dan kimia tanah serta berperan dalam menambah bahan organik tanah (Maisyaroh, 2010).

\section{Lokasi dan Waktu Penelitian}

\section{METODE PENELITIAN}

Penelitianinidilaksanakandi Kawasan Taman Wisata Alam BaumataDesa Baumata Kecamatan

Taebenu Kabupaten Kupang mulai bulan Februari sampai bulan Maret 2018

\section{Alat Dan Bahan}

Alat yang digunakan dalam penelitian ini adalah kamera digunakan untuk mengambil gambar tumbuhan sebagai bukti fisik, GPS (global position system) digunakan untukmenentukan titik koordinat, rol meter untuk mengukur panjang dan lebar transek juga untuk mengkur jarak antar plot juga jarak antar stasiun, talirafia untuk membuat line transek dan plot, alat tulis menulis sebagai alat untuk mencatat semua pengamatan yang dilakukan di lapanggan, gunting digunakan untuk memotong tali rafia yang di gunakan. Bahan yang digunakan dalam penelitian ini yaitu, tanaman herba.

Teknik Pengumpulan Data 
Teknik pengumpulan data mengunakan metode kombinasi transek bergaris dan metode kuadran (Kusmana, 1996). Ditentukannya 4 stasiun yaitu dekat mata air, semak, tegakan pohon dan bebatuan dengan jarak dari stasiun dekat mata air ke stasiun semak $102 \mathrm{~m}$, dari stasiun semak ke stasiun tegakan pohon $89 \mathrm{~m}$, dari stasiun tegakan pohon ke stasiun bebatuan $80 \mathrm{~m}$ dan dari stasiun bebatuan ke stasiun dekat mata air $76 \mathrm{~m}$. Dilakukan pemasangan transek dengan pada setiap stasiun dengan ukuran $35 \mathrm{~m}$ × $35 \mathrm{~m}$ dan plot yang berukuran $10 \mathrm{~m} \times 10 \mathrm{~m}$ sebanyak 4 plot dengan jarak tiap plot $5 \mathrm{~m}$.

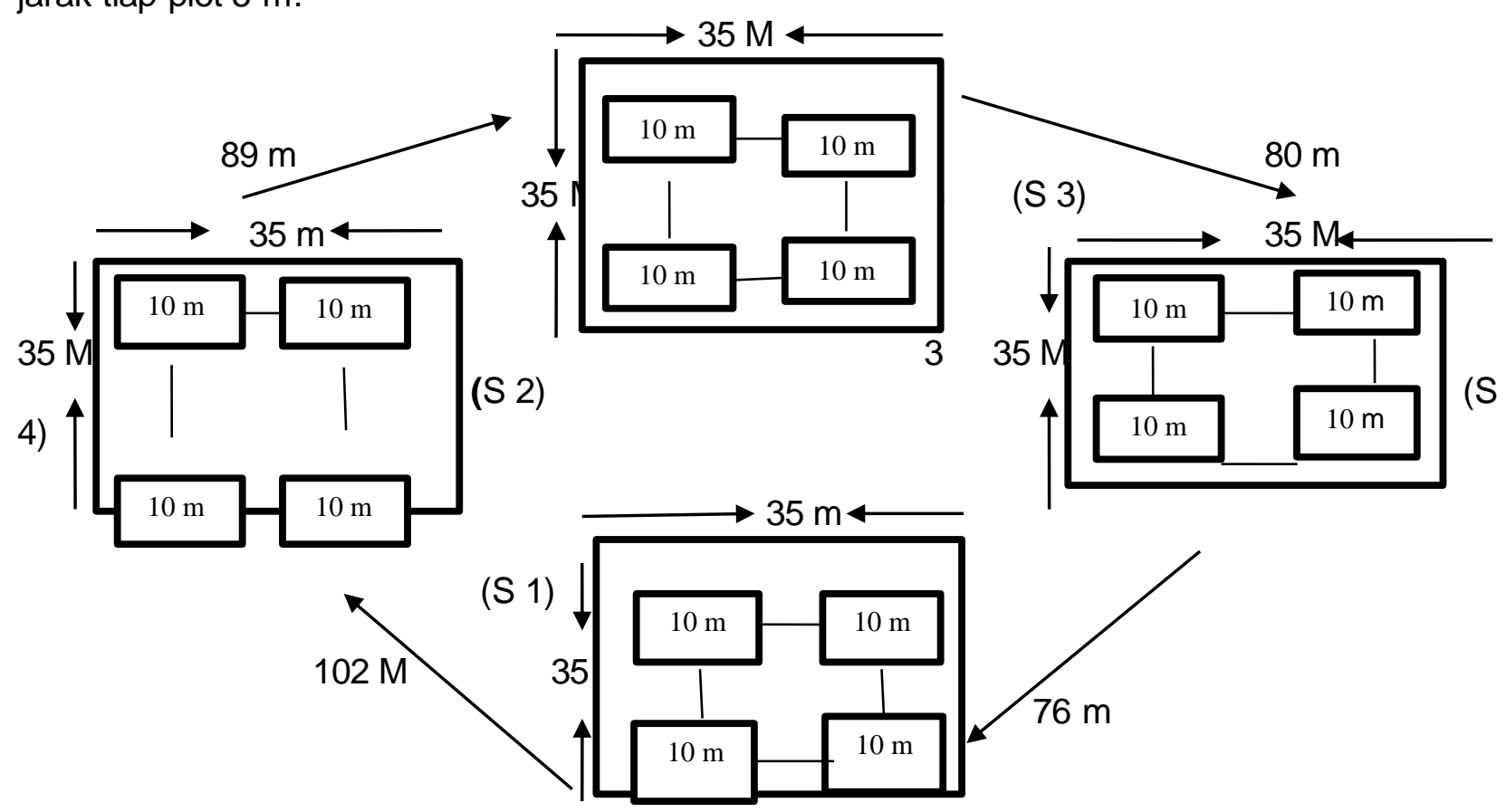

\section{Prosedur Penelitian \\ Di lapangan}

Gambar 1. Desain Stasiun, Line Transek dan Plot Pengamatan

Peneliti melakukan observasi langsung kelokasi penelitian dengan tujuan untuk mengetahui gambaran lokasi, situasi dan kondisi lapangan yang dijadikan sebagai tempat penelitian untuk mendapatkan data yang dibutuhkan. Menentukan titik koordinat pada tempat pengamatan dan pengambilan sampel dengan alat bantu GPS. Dipilihnya 4 stasiun untuk pengambilan sampel yaitu stasiun didekat mata air, direrumputan/semak, ditegakan pohon dan dibebatuan. Pemilihan berdasarkan pengamatan dan 4 stasiun ini dapat mewakili keseluruhan wilayah di TWA Baumata.Memasang transek pada tiap stasiun berukuran $35 \mathrm{~m}$ × $35 \mathrm{~m}$ dan memasang plot pada tiap stasiun berukuran $10 \mathrm{~m} \times 10 \mathrm{~m}$ dengan jarak tiap plot $5 \mathrm{~m}$. Pada setiap plot akan diamatijenis tanaman herba kemudian di foto sebagai bukti fisik, setelah itu tumbuhan diidentifikasiciri morfologinya bentuk akar,batang,daun bunga dan buah dengan bantuan buku Diversitas Jenis Tumbuhan di Sekitar Kita (Kurnianingtyas, dkk. 2004).

\section{Identifikasi Tumbuhan}

Identifikasi tumbuhan didasarkan pada ciri-ciri morfologi. Mengamati ciri-ciri morfologinya baik akar, batang, dan daun serta bunga. Bentuk morfologinyadicocokkan dengan gambar, tulisan-tulisan dan bukuyang relevan dalamhal ini buku yang digunakan adalah diversitas jenis tumbuhan di sekitar kita (Kurnianingtyas, dkk. 2004) dan di bantu oleh lbu Dra. Sardina Ndukang M.Pd dan Bapak DR. Leonardus Bani Lodhu, MS (Komonikasi pribadi)

\section{Analisis Data}

Seluruh tanaman herba yang diperoleh dikelompokkan berdasarkan famili, untuk melihat presentasi famili terbanyak, untuk setiap spesies herba di deskripsikan morfologinya disertai gambar serta menghitung keanekaragaman tanaman herba dengan menggunakan rumus keanekaragaman Shannon-Wiener (Magurran,1988)

Indeks Keragaman Shannon-Wiener dihitung mengunakan rumus:

$$
H^{\prime}=-\sum_{i=1}^{S} p i \ln p i
$$


Ket.

$\mathrm{Pi} \quad=\sum \mathrm{ni} / \mathrm{N}$

$\mathrm{H} \quad$ : Indeks Keragaman Shannon-Wiener

$\mathrm{Pi} \quad$ : Jumlah individu suatu spesies/jumlah total seluruh spesies

ni : Jumlah individu spesies ke-i

$\mathrm{N} \quad$ : Jumlah total individu

Kriteria penilaian berdasarkan keanekaragaman jenis:

$\mathrm{H}^{\prime} \leq 1 \quad$ : Keanekaragaman rendah.

$1<\mathrm{H}^{\prime} \leq 3 \quad$ : Keanekaragaman sedang.

$\mathrm{H}^{\prime}>3 \quad$ : Keanekaragaman tinggi

\section{HASIL DAN PEMBAHASAN}

\section{Jenis- jenis Tanaman Herba yang ditemukan di TWABaumata}

Berdasarkan hasil penelitian pada Tabel 1 tanaman herba yang ditemukan di TWA Baumata pada 4 stasiun yaitu pada stasiun didekat mata air (stasiun 1)tanaman herba yang ditemukan berjumlah 8 spesies dan 7 famili. Berdasarkan data tersebut maka kelompok tumbuhan yang mendominasi stasiun ini adalah familiAsteraceae yang terdiri dari spesies Syenedrella nodiflora L, Bindes pilosa L sedangkan famili lainya hanya memiliki 1 spesies yaitu famili Amaranthaceae yaituAmaranthus viridis L, familiPortulaceae yaitu Portulaca oleraceae $\mathrm{L}$, famili Euphorbiaceae yaitu Euphorbia hirta L, famili polypodiaceae yaitu Pityrograma colemelanus L, familiCostaceae yaitu Costus spesiosus Smith, dan familiAraceae yaitu Homalomena occulta L, dengan jumlah keseluruhan individu pada stasiun ini adalah 164 individu.

Tabel 1 Keanekaragaman Jenis Tumbuhan Herba di TWA Baumata (Individu/m²)

\begin{tabular}{lllllll}
\hline No & Famili & Spesies & \multicolumn{3}{c}{ Stasiun } \\
& & & I & II & III & IV \\
\hline 1 & Amaranthaceae & Amaranthus viridis L & 7 & 0 & 0 & 0 \\
\hline 2 & Portulaceae & Portulaca oleraceae L & 29 & 17 & 14 & 19 \\
\hline 3 & Euphorbiaaceae & Euphorbia hirta L & 26 & 9 & 16 & 23 \\
\hline 4 & polypodiaceae & Pityrograma colemelanos L & 9 & 0 & 0 & 0 \\
\hline 5 & Asteraceae & Syenedrella nodiflora L & 12 & 14 & 6 & 9 \\
\hline 6 & Asteraceae & Binden pilosa L & 36 & 0 & 0 & 0 \\
\hline 7 & Costaceae & Costus spesiosus Smith & 22 & 14 & 9 & 15 \\
\hline 8 & Araceae & Homalmena occulta L & 23 & 0 & 0 & 0 \\
\hline & TOTAL & & 164 & 54 & 45 & 66 \\
\hline
\end{tabular}

(Sumber data: olahan penelitian, 2018)

Di stasiun rerumputan/semak (stasiun 2), di stasiun tegakan pohan (stasiun 3), dan di stasiun bebatuan (stasiun 4) ditiga stasun ini ditemukan 4 jenis spesies dan 3 famili tanaman herba. famili yang mendominasi 3 stasiun ini adalah familiAsteraceae yang terdiri dari spesies Syenedrella nodiflora L, Bindes pilosa L sedangkan familiPortulaceae memilki 1 spesies yaitu Portulaca oleraceae L, family Euphorbiaaceae yaitu Euphorbia hirta $L$ dengan jumlah individu pada stasiun rerumputan/semak adalah 54 individu, di stasiun tegakan pohon adalah 45 individu dan pada stasiun bebatuan adalah 66 individu. Dengan demikian maka jumlah total individu pada semua stasiun adalah 329 individu dan secara keseluruhan ditemukan 8 jenis spesies dan 7 famili tanaman herba di Taman Wisata Alam Baumata.

Dari keseluruhan hasil penelitian tanaman herba di stasiun dekat mata air mempunyai jumlah individu tertinggi karena didekat mata air ketersediaan airnya banyak. Tanaman Herba membuhtuhkan air dalam jumlah besar untuk penyerapan. Didekat mata air kelembaban udara (kandungan uap air di udara) dan kelembaban tanah yang tinggi sehingga kelembaban dibutuhkan oleh tanaman herba agar tidak cepat kering karena penguaapan. 


\section{Indigenous Biologi \\ Jurnal pendidikan dan Sains Biologi \\ Volume 1(3) 2018}

Berdasarkan hasil penelitian di atas kelompok tumbuhan herba yang memiliki jumlah individu paling dominan pada penelitian ini adalah spesies Portulaca oleraceae $L$, yang mana pada stasiun didekat mata air terdapat 29 individu, pada stasiun rerumputan/semak terdapat 17 individu, pada stasiun tegakan pohon terdapat 14 individu dan pada stasiun bebatuan terdapat 19 individu dengan jumlah total pada semua individu pada semua stasiun adalah 82 individu. Portulaca oleraceae $\mathrm{L}$ mempunyai jumlah individu yang banyak karena Portulaca oleracea Ladalah tanaman yang tumbuh liar di hutan tanaman ini dapat tumbuh di daerah yang berbatu maupun berpasir. Tumbuhan ini dapat tumbuh meski kekurangan air dan memiliki sifat adaptasi yang baik terhadap lingkungan (Dalimartha, 2009).

Spesies yang mempunyai individu paling sedikit dari semua stasiun adalah Amarathus Viridis L karena hanya terdapat di Stasiun didakat mata air dengan jumlah 7 individu, karena Amarathus Viridis $L$ hanya mamputumbuh pada keadaan lahan harus terbuka dan mendapat sinar matahari serta memiliki tanah yang subur, tanah yang lembab, gembur, banyak mengandung bahan organik (Rukmana, 1995).

\section{Indeks Keanekaragaman Tanaman Herba Di Kawasan TWA Baumata}

Tabel 2 Indeks keanekaragaman (Shannon-wiener indeks) jenis tanaman herba di TWA Baumata.

\begin{tabular}{lllll}
\hline & Stasiun 1 & Stasiun 2 & Stasiun 3 & Stasiun 4 \\
\hline Shonnon Index $\left(\mathrm{H}^{\prime}\right)$ & 1.96 & 1.36 & 1.32 & 1.33 \\
\hline Jumlah Spesies & 8 & 4 & 4 & 4
\end{tabular}

(Sumber data: olahan penelitian, 2018)

Berdasarkan data tabel 4.2.1 di atas dapat diketahui bahwa indekskeanekaragaman tumbuhan herba di TWA Baumata pada seluruh titik pengamatan yaitu pada stasiun 1 dengan H' indeks $=1.96$, stasiun 2 dengan $H^{\prime}$ indeks $=1.36$, stasiun 3 dengan $H^{\prime}$ indeks $=1.32$, dan pada stasiun 4 dengan $\mathrm{H}^{\prime}$ indeks = 1.33 dengan demikian maka keanekaragaman tanaman herba pada setiap stasiun adalah keanekaragaman sedang. Penggolongan iniberdasarkan kriteria yang ditetapkan Shannon-Wiener (Magurran,1988) yaitu jika $H^{\prime} \leq 1$ Keanekaragaman rendah, bila $1<H^{\prime}$ $\leq 3$ Keanekaragaman sedang dan $\mathrm{H}^{\prime}>3$ Keanekaragaman tinggi.

Hasil penelitian menunjukkan bahwa stasiundekat mata airmerupakan lokasi penelitian yang paling banyak ditemukan jenis tumbuhan herba dengan jumlah 8 spesiesdengan indeks keanekaragaman paling tinggi $\left(H^{\prime}=1,96\right)$ dari stasiun lainya. Banyaknya tumbuhan herba pada stasiun didekat mata ait tersebut kemungkinan disebabkan oleh faktor lingkungan seperti kelemababan tanah, kelembaban udara,pH tanah maupun suhu yang mendukung pertumbuhan (KSDA Kabupaten kupang) dan juga tercukupinya ruang, nutrisi, dan sinar matahari bagi pertumbuhan herba di stasiun ini.Stasiun 3 (tegakan pohon) merupakan lokasi penelitian yang memiliki indeks keanekaragaman paling rendah dari stasiun lainya, disebabkan naungan pohon yang banyak sehingga cahaya sulit masuk untuk proses fotosintesis.

\section{Deskripsi dan klasifikasi jenis-jenis tanaman herba yang ditemukan di TWA Baumata. Amarathus viridis L. (Bayam/ut kase)}

Amarathus viridis L. (nama lokal : ut kase) merupakam tanaman herba yang ditemukan di TWA Baumata pada stasiun didekat mata air yang memiliki tiinggi berkisar $22-50 \mathrm{~cm}$. Batang, panjang, licin, tanpa rambut, sering berwarna hijau. Daun, bentuk jorong dan juga belah ketupat, panjang $6 \mathrm{~cm}$, lebar $3,5 \mathrm{~cm}$, licin tanpa rambut, ujung meruncing, panjang tangkai $2,2 \mathrm{~cm}$. Bunga, hijau, ramping, bunga bulir terdapat di ujung atau ketiak batang. Manfaat: sebagai tumbuhan penutup tanah, dan juga sebagai sayuran (Kurnianingtyas, dkk. 2004) dengan memiliki klasifikasinya sebagai berikut:

$\begin{array}{ll}\text { Kingdom } & \text { : Plantae } \\ \text { Sub kingdom } & \text { : Tracheobionta } \\ \text { Divisi } & \text { : Spermatophyta } \\ \text { Sub divisi } & \text { : Angiospermae } \\ \text { Class } & \text { : Magnoliopsida } \\ \text { Ordo } & \text { : Caryophyllales } \\ \text { Familly } & \text { : Amaranthaceae } \\ \text { Genus } & \text { : Amarathus }\end{array}$




\section{Indigenous Biologi Jurnal pendidikan dan Sains Biologi Volume 1(3) 2018}

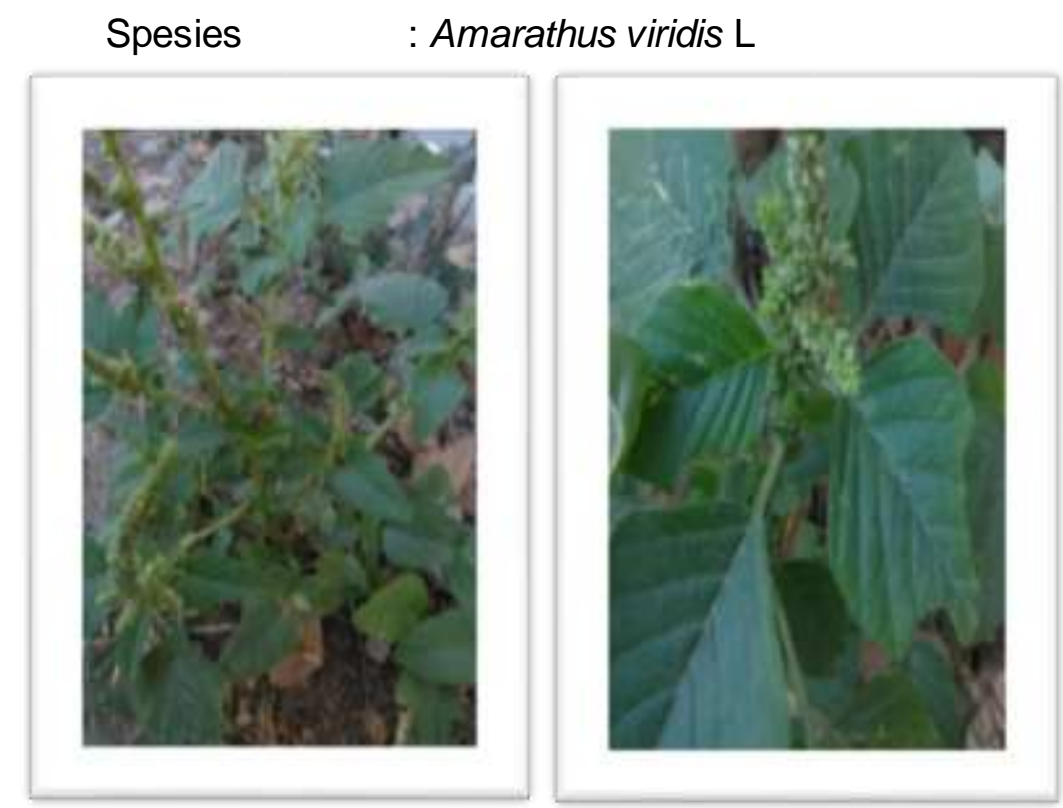

Gambar 2. Amarathus viridis L (Dokumentasi Pribadi, 2018)

\section{Portulaca oleraceae L. (Uta kleo)}

Portulaca oleraceae L. (nama lokal : uta kleo) merupakan tanaman herba yang ditemukan di TWA Baumata pada stasiun didekat mata sir, semak, naungan pohon, dan bebatuan yang memilikiBatang, bentuk bulat, berwarna merah keunguan, bercabang, berair, berdaging, panjang 20 $\mathrm{cm}$, ruas tanpa rambut, bercabang banyak. Daun, tersebar, bentuk bulat sendok, jorong, panjang daun $2 \mathrm{~cm}$, lebar $1,3 \mathrm{~cm}$, bertangkai pendek. Manfaat: sebagai penutup tanah, dapat di konsumsi, obat untuk berbagai penyakit seperti: kesehatan jantung, mencega resiko kanker, kesehatan mata dan sebagai kerajinan tangan (Kurnianingtyas, dkk. 2004) dengan memiliki klasifikasi sebagai berikut:

$\begin{array}{ll}\text { Kingdom } & \text { : Plantae } \\ \text { Sub Kingdom } & \text { : Tracheobionta } \\ \text { Divisi } & \text { : Spermatophyta } \\ \text { Sub Divisi } & \text { : Angiospermae } \\ \text { Class } & \text { : Magnoliopsida } \\ \text { Ordo } & \text { : Caryophyllales } \\ \text { Familly } & \text { : Portulaceae } \\ \text { Genus } & \text { : Portulaca } \\ \text { Spesies } & \text { : Portulaca Oleraceae L }\end{array}$




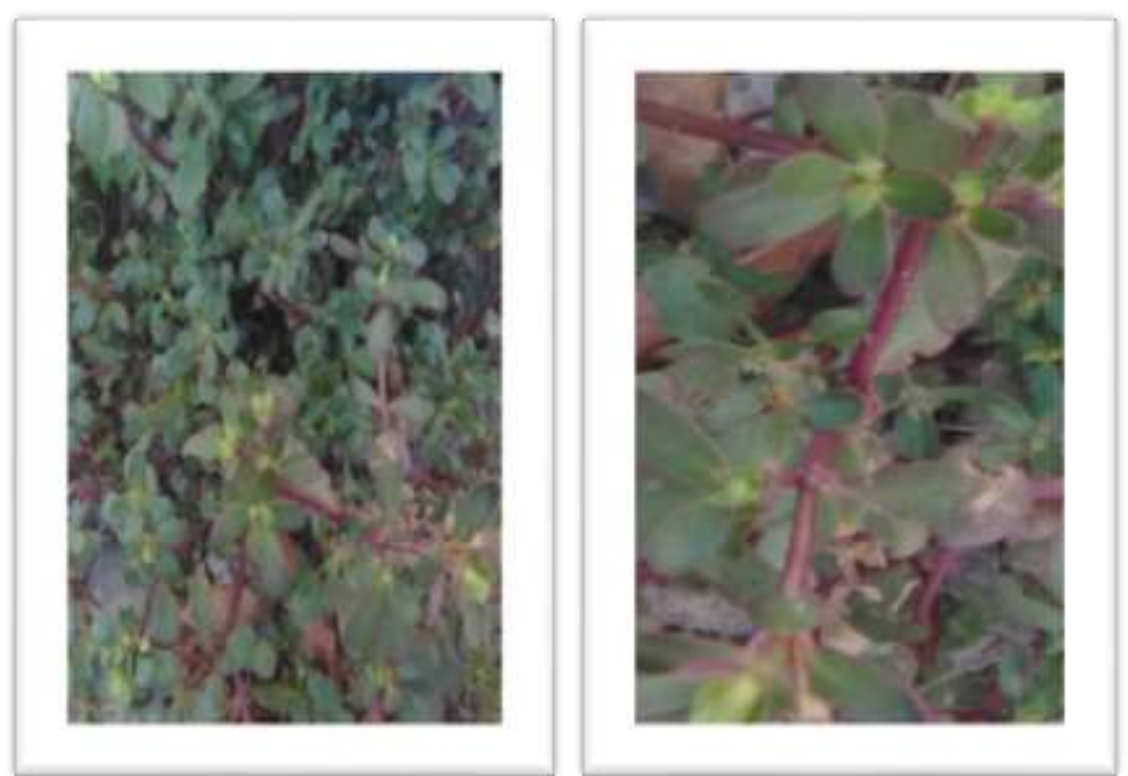

Gambar 3 Portulaca oleraceae L. (Dokumentasi Pribadi, 2018)

\section{Euphorbia hirta L. (Patikan kerbo)}

Euphorbia hirta L. (Patikan kerbo) adalah tanaman herba yang ditemuka di TWA Baumata pada stasiun didekar mata air, semak, naungan pohon dan bebatuan yang memiliki Tinggi berkisar 9-25 cm. Batang, lunak, penampang bulat, berbuluh, bergetah putih, warna hijau kecoklatan. Daun, tunggal, berhadapan, lanset, pangkal dan ujung runcing, tepi bergerigi, permukaan atas dan bawah berbulu, panjang daun $2 \mathrm{~cm}$, lebar $1 \mathrm{~cm}$, warna hijau keunguan. Bunga, majemuk, tumbuh di ketiak daun, ungu kehijaun, berambut menempel. Manfaat: sebagai tumbuhan penutup tanah, obat untuk berbagai penyakit seperti: asma, brokitis, batuk, peluruh air seni, syhiphilis, dan siriawan, infulensa, disentri, kurang darah, radang paru-paru, radang usus, digigit ular berbisa (getahnya), penyakit kulit (Kurnianingtyas, dkk. 2004) dengan klasifikasinya sebagai berikut:

$\begin{array}{ll}\text { Kingdom } & \text { : Plantae } \\ \text { Sub Kingdong } & \text { : Tracheobionta } \\ \text { Divisi } & \text { : Spermatophyta } \\ \text { Sub divisi } & \text { : Angiospermae } \\ \text { Class } & \text { : Magnoliopsida } \\ \text { Ordo } & \text { : Euphorbiales } \\ \text { Familly } & \text { : Euphorbiaceae } \\ \text { Genus } & \text { : Euphorbia } \\ \text { Spesies } & \text { : Euphorbia hirta L. }\end{array}$


Indigenous Biologi Jurnal pendidikan dan Sains Biologi Volume 1(3) 2018
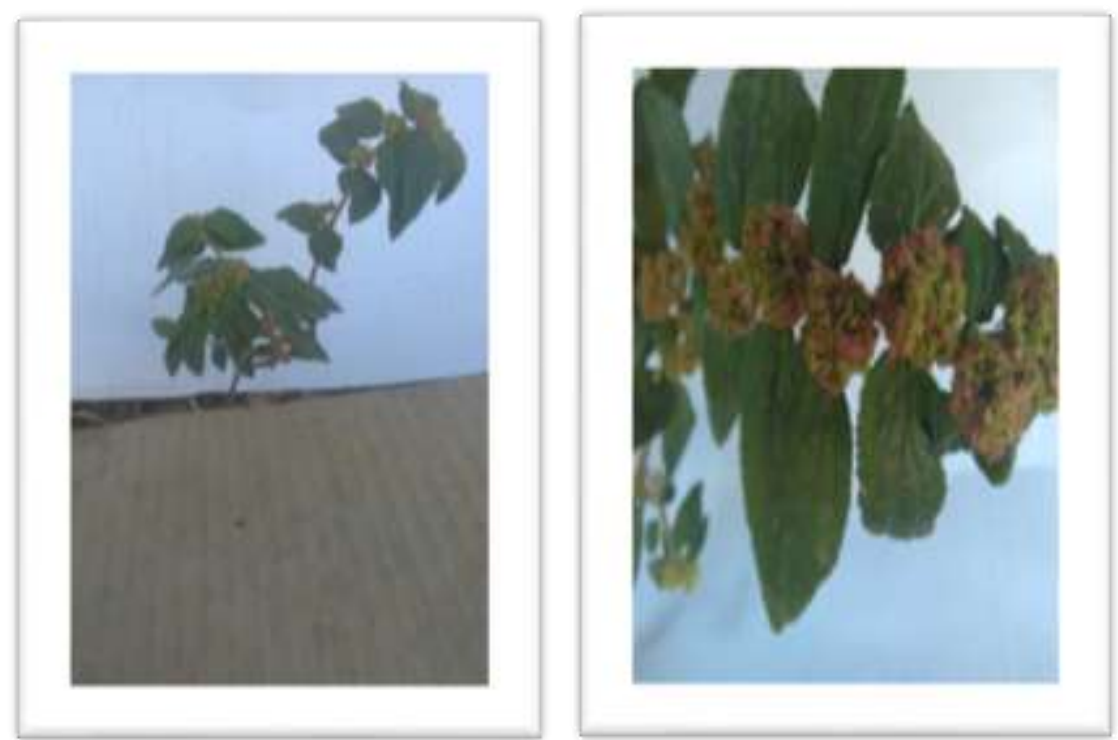

Gambar 4. Euphorbia hirta L (Dokumentasi pribadi, 2018)

\section{Pityrograma colemelanus L. (Mil mili)}

Pityrograma colemelanus $\mathrm{L}$ (nama lokal : mil mili) adalah tanaman herba yang ditemukan di TWA Baumata pada stasiun didekat mata air dengan tinggi berkisar $37-70 \mathrm{~cm}$. Batang, bulat, berwarna hijau, berkilat. Daun, beringgit, menyirip, lebar $\mathrm{c} \mathrm{cm}$, panjang $9 \mathrm{~cm}$, permukaan atas hijau, permukaan bawah kuning keperakan. Manfaat: sebagai obat ginjal (Kurnianingtyas, dkk. 2004) yang memiliki klasifikasi sebagai berikut:

$\begin{array}{ll}\text { Kingdom } & \text { : Plantae } \\ \text { Sub Kingdom } & \text { : Tracheobionta } \\ \text { Divisi } & \text { : Pteridophyta } \\ \text { Class } & \text { : Pteridopsida } \\ \text { Sub Kelas } & \text { : Polypoditae } \\ \text { Ordo } & \text { : Polypodiales } \\ \text { Familly } & \text { : Polypodiaceae } \\ \text { Genus } & \text { : pityrogramma } \\ \text { Spesies } & \text { : pityrogramma colemelanus L. }\end{array}$

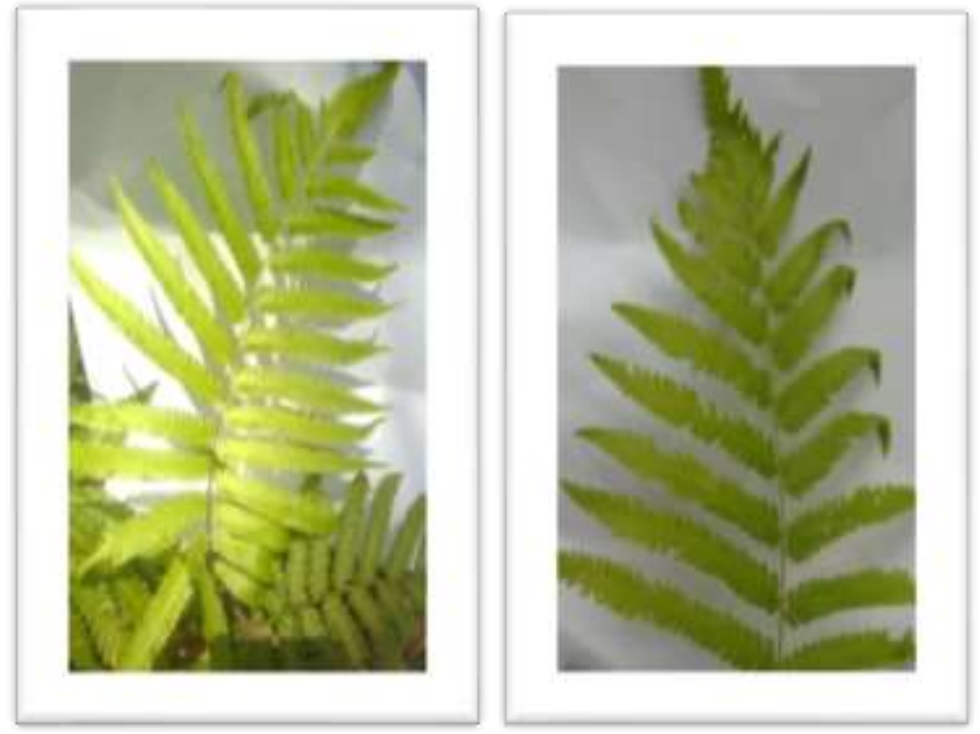

Gambar 5 Pityrograma colemelanus L.

Syenedrella nodiflora L. (Fafi soso) 


\section{Indigenous Biologi Jurnal pendidikan dan Sains Biologi \\ Volume 1(3) 2018}

Syenedrella nodiflora L ( nama lokal : fafi soso) adalah tanaman herba yang ditemukan di TWA Baumata pada stasiun didekat mata air, semak, naungan pohon dan bebatuan dengan tinggi berkisar 30-60 cm. Batang, bercabang, permukaan berambut, warna keunguan. Daun, tunggal, lonjong, bersilng berhadapan, panjng $4.3 \mathrm{~cm}$, lebar $2 \mathrm{~cm}$, tepi bergerigi, ujung runcing, pangkal meruncing, pertulangan menyirip, permukaan berambut, tangkai bulat dan berwarna hijau. Bunga, majemuk, dengan atau tanpa ibu tangkai, bunga tumbuh di ketiak daun dan ujung batang, mahkota kuning. Manfaat: sebagai hebsida, dan penggangu tanaman budaya (Kurnianingtyas, dkk. 2004) denagn klasifikasi sebagai berikut

$\begin{array}{ll}\text { Kingdom } & \text { : Plantae } \\ \text { Sub Kingdom } & \text { : Tracheobionta } \\ \text { Divisi } & \text { : Spermatophyta } \\ \text { Sub divisi } & \text { : Angiospermae } \\ \text { Class } & \text { : Magnoliopsida } \\ \text { Ordo } & \text { : Asterales } \\ \text { Familly } & \text { : Asteraceae } \\ \text { Genus } & \text { : Syenedrella } \\ \text { Spesies } & \text { : Syenedrella nodiflora L. }\end{array}$

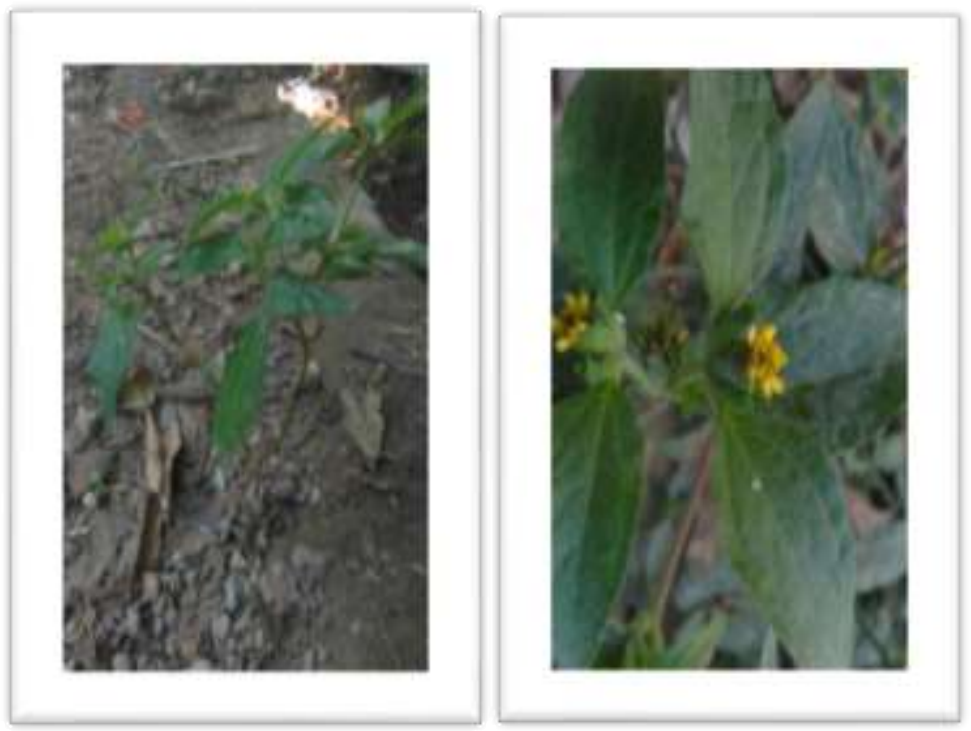

Gambar 6 Syenedrella nodiflora L

\section{Costus spesiosusSmith. (Puni)}

Costus spesiosus Smith (puni) adalah tanaman herba yang ditemukan di TWA Baumata pada stasiun didekat mata air dengan tinggi berkisar $82 \mathrm{~cm}-2 \mathrm{~m}$. Batang, lunak, licin, beruas, tertutup pelepah daun, hijau, melingkar satu putaran. Daun, tunggal, lanset memanjang, ujung meruncing, tepi rata, permukaan bawah berbuluh lembut, panjang $9 \mathrm{~cm}$, lebar $5,3 \mathrm{~cm}$, tangkai pendek, duduk melingkar pada batang, berwarna hijau. Manfaat: sebagai obat untuk penyakit sperti: kencing nanah, obat syphilis, obat trachoma, disentri, obat luka, bekas gigitan serangga (Kurnianingtyas, dkk. 2004) dengan klasifikasi sebagai berikut:

$\begin{array}{ll}\text { Kingdom } & \text { : Plantae } \\ \text { Sub Kingdom } & : \text { Tracheobionta } \\ \text { Divisi } & : \text { Spermatophyta } \\ \text { Sub divisi } & : \text { Angiospermae } \\ \text { Class } & : \text { Liliopsida } \\ \text { Ordo } & : \text { Zingeberales } \\ \text { Familly } & : \text { Costaceae } \\ \text { Genus } & : \text { Costus } \\ \text { Spesies } & : \text { Costus Spesiosus Smith. }\end{array}$


Indigenous Biologi Jurnal pendidikan dan Sains Biologi Volume 1(3) 2018
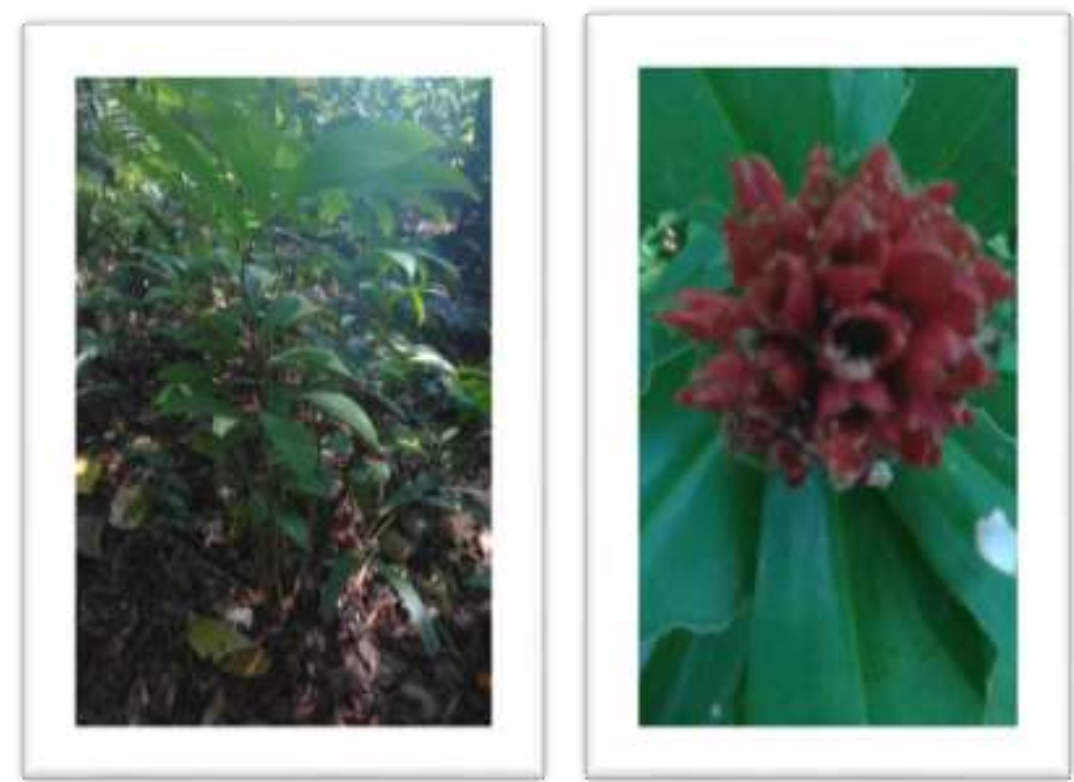

Gambar 7 Costus spesiosus Smith

\section{Bindes pilosa L. (Nab nefo)}

Bindes pilosa $\mathrm{L}$ ( nab nefo) adalah tanaman herba yang ditemukan di TWA Baumata pada stasiun didekat mata air, semak, naungan pohon dan bebatuan dengan tinggi berkisar $10-40 \mathrm{~cm}$. Batang, segi empat hijau, bercang cabang, tunggal, berhadapan, bentuk bulat telur, ujung runcing, tepi bergerigi, panjng $4 \mathrm{~cm}$, lebarr $3,2 \mathrm{~cm}$, panjng tangkai $7 \mathrm{~cm}$. Bunga, tumbuh di ujung batang, bunga tabung berwarna kuning, bunga pita berwarna putih. Manfaat: sebagi obat pada berbagai penyakit seperti: demam, flu, hepatitis akut, infeksi saluran urine, mencegah stroke, penyakit kulit, gaangguan pencernaan dan perut, sakit kepala, sariawan, gigitan ular, malaria. Termasuk tanaman herba (Kurnianingtyas, dkk. 2004) dengan klasifikasi sebagai berikut:

$\begin{array}{ll}\text { Kingdom } & \text { : Plantae } \\ \text { Sub Kingdom } & \text { : Tracheobionta } \\ \text { Divisi } & \text { : Spermatophyta } \\ \text { Sub divisi } & \text { : Angiospermae } \\ \text { Class } & \text { : Magnoliopsida } \\ \text { Ordo } & \text { : Asterales } \\ \text { Familly } & \text { : Asteraceae } \\ \text { Genus } & \text { : Bidens } \\ \text { Spesies } & \text { : Bidens Pilosa L. }\end{array}$
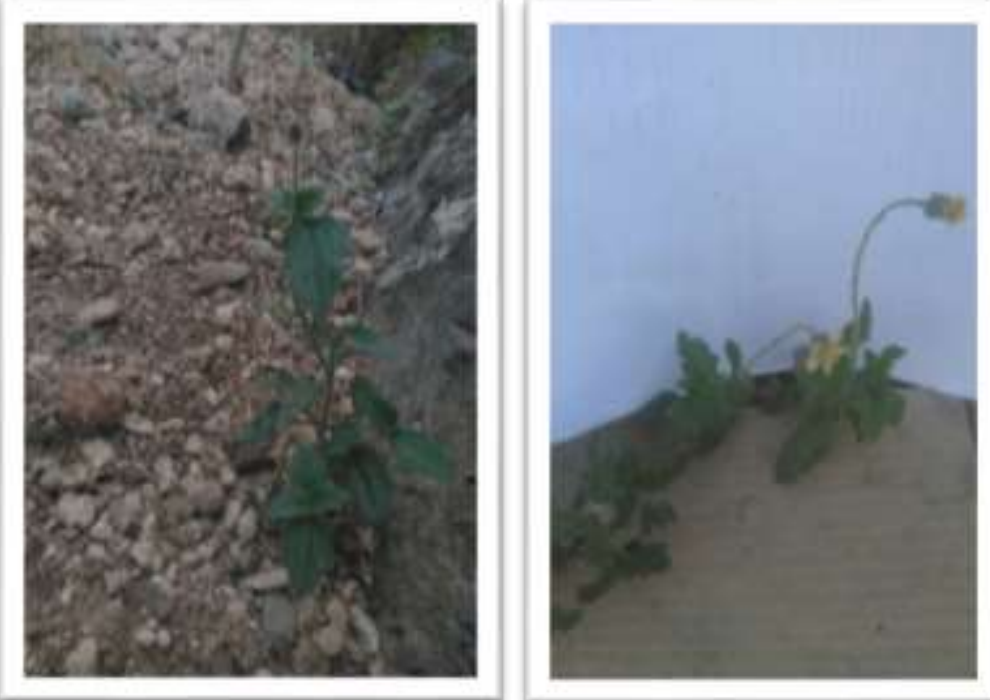


\section{Indigenous Biologi \\ Jurnal pendidikan dan Sains Biologi \\ Volume 1(3) 2018}

Gambar 8. Bindes pilosa (Dokumentasi Pribadi, 2018)

Homalomena occulta L. (Keladi oe)

Homalomena occulta $L$ (keladi oe)adalah tanaman herba yang ditemukan di TWA Baumata pada stasiun didekat mata air dengan tinggi berkisar $12-35 \mathrm{~cm}$. berbatang bulat, tidak berkayu, warna hijau, membentuk rimpang. Daun, tunggal, panjng tangkai $3 \mathrm{~cm}$, bulat berdaging, helaian daun berbentuk jantung, ujung runcing, tepi rata, kedua permukaan licin, pertulangan menyirip, panjang $7 \mathrm{~cm}$, lebar 5,4 cm, dan berwarna hijau. Termasuk tanaman herba. Manfaat: sebagai obat hati dan ginjal (Tropilab, 2012) dengan klasifikasi sebagai berikut:
Kingdom
: Plantae
Sub Kingdom
Divisi
Sub divisi
Tracheobionta
Class
Ordo
Familly
: Spermtophyta
Genus
Spesies
Angiospermae
: Liliopsida
Sumber
: Alismatales
: Araceae
: Homalomena
: Homalomena occulta L
: (Tropilab, 2012)
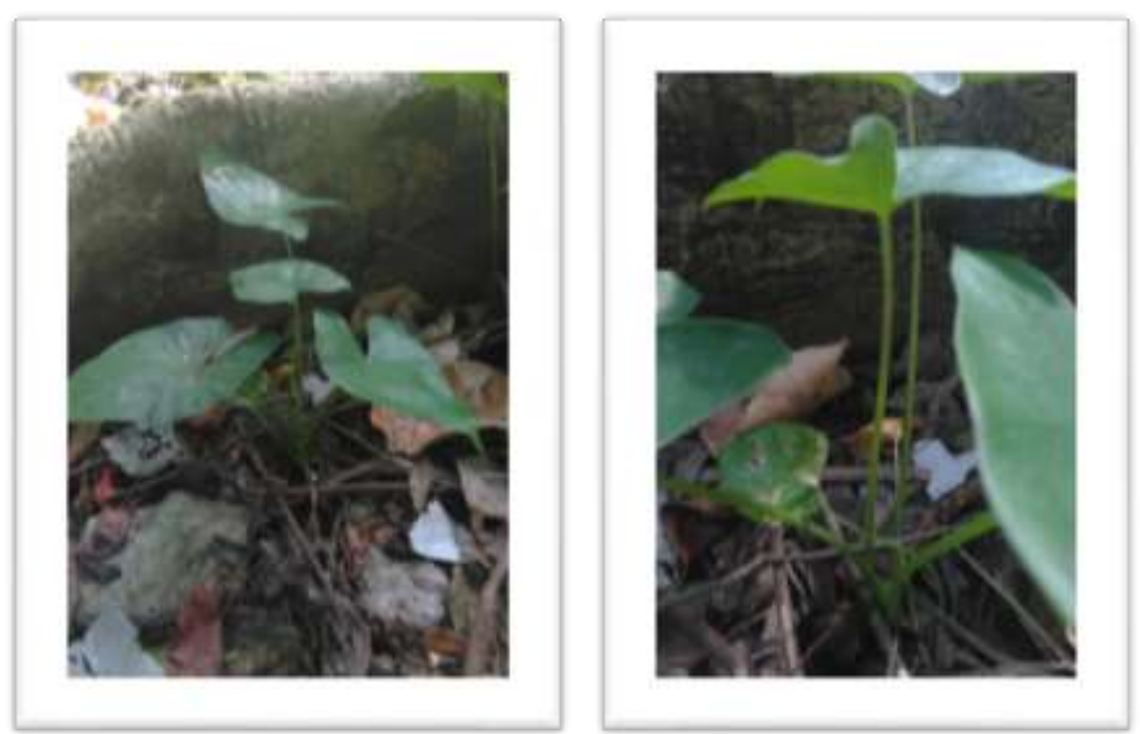

Gambar 4.3.8.1. Homalomena occulta L. gambar 4.3.8.2. Batang (Dokumentasi Pribadi, 2018)

Manfaat Tanaman Herba oleh Masyarakat Sekitar di TWA Baumata.

Dari hasil penelitian ada tanaman herba yang dapat di konsumsi oleh masyarakat sekitar di TWA Baumata sebagai sayuran yaitu Amarathus viridis $L$ karena kandungan nutrisi yang terdapat dalam 100 gram daun bayam adalah 2,3 gram protein, 3,2 gram karbohidrat, 3 gram besi dan 81 gram kalsium. Amarathus viridis L, juga kaya akan berbagai macam vitamin dan mineral, yakni vitamin $A$, vitamin $C$, niasin, thiamin, fosfor, riboflavin, natrium, kalium dan magnesium.

Tanaman herba yang digunakan sebagai bat-obatan yaitu Portulaca oleraceae $L$ dan Euphorbia hirta $\mathrm{L}$ yang memiliki kandungan senyawa flavonoid, senyawa alkaloid, senyawa flavonoid dan senyawa tanin (Lenny, 2006), Pityrograma colemelanus L mengandung senyawa flavonoid, Costus spesiosus Smith pada daun Costus speciosus mengandung saponin, flavonoida, dan tanin. Batangnya mengandung saponin, flavonoida dan tanin.Rimpangnya mengandung saponin, flavonoida, tanin dan alkaloida.Bunganya mengandung saponin, flavonoida dan polifenol. Bindes pilosaL mengandung senyawa kimia diantaranya alkaloid, saponin, zat pahit, minyak atsiri dan zat samak (Setiawati, 2008). Homalomena Occulta pada rimpangnya menggandung Saponin, flavonoid, tannin dan polifenol.

\section{Kesimpulan}

\section{PENUTUP}




\section{Indigenous Biologi \\ Jurnal pendidikan dan Sains Biologi \\ Volume 1(3) 2018}

Berdasarkan hasil penelitian yang dilakukan di Taman Wisata Alam Baumata, desa Baumata kecamatan Taebenu, maka disimpulkan bahwa indeks keanekaragaman tumbuhan herba di TWA Baumata yang di peroleh pada semua stasiun adalah keanekaragaman sedang. Juga ditemuka 8 jenis tanaman Herba yaitu Amarathus viridis L, Portulaca oleraceae L, Euphorbia hirta L, Pityrogramma colemelanus L, Syenedrella nodiflora L, Costus spesiosus Smith. Bindens pilosa L, Homalomena occulta L.

Saran

Perlu lebih menjaga dan melestarikan tumbuhan herba agar dapat lebih menjaga keseimbangan ekosistem dan memperkuat struktur tanah hutan dan Penelitian ini dilakukan untuk memudahkan masyarakat dalam mengenali jenis-jenis tumbuhan herba yang terdapat di kawasan TWA Baumata.

\section{DAFTAR PUSTAKA}

Agustina, D. K. 2010. Vegetasi Pohon di Hutan Lindung. Malang. UIN Press

Aspan, R. 2008. Taksonomi Koleksi Tanaman Obat Kebun Tanaman Obat. Bidang Biologi LIPI. Citeureup.

Dalimartha S. 2009. Atlas Tumbuhan Obat Indonesia. Jakarta: Puspa Swara. Halaman 154-159.

Egtis. 1989. Pengantar Ekologi Tropika. Penerbit IPB. Bandung.

Ewusie, J.Y. 1990. Pengantar Ekologi Tropika. Bandung: Tanuwijaya IPB

Hardjosentono P. 1976. Pedoman Inventarisasi Flora dan Fauna Bogor. Direktorat Perlindungan dan Pengawetan Alam.

Kurnianingtyas I, Purnomo E dan Arisoesilaningsih E. 2004. Diversitas Jenis Tumbuhan di Sekitar Kita. Laboratorium Ekologi dan Hewan Jurusan Biologi Fakultas MIPA Universitas Brawijaya. Malang

Kurdi, A. 2011.Bagian Dari Tanaman Yang Digunakan Untuk Obat. Skripsi. Fakultas Pertanian. Universitas Muhamadiyah. Malang.

Kusmana, C. 1996. Metode Survei Vegetasi. Bogor. IPB Press

Kusmana, C. 1997. Metode Survei Vegetasi. Bogor. IPB Press

KSDA Kabupaten Kupang. 2014. Tentang Kawasan Hutan dan Konservasi Perairan Proponsi Nusa Tenggara Timur Taman Wisata Alam Baumata.

Magurran AE. 1988. Ecological Diversity and its Measurement. New Jersey :Prienton Uneversity Press.

Lenny, S. 2006. Senyawaflavonoid, fenil, profanoiddan alkaloid. Medan.

Longman KA danJenik J. 1987. Tropical Forest Ecology. An Imprint of Champman and Hall. Boundary Row. London

Maisyaroh, W. 2010.Struktur Komunitas Tumbuhan Penutup Tanah di Taman Hutan Raya $R$. SoerjoCangar, Malang.Jurusan Tarbiyah, SekolahTinggi Agama Islam NegeriJember

Makalalag, I. 2014. Inventarisasi Jenis Tumbuhan Obat Tradisional di Kecamatan Pinolosian Kabupaten Bolaang Mongondow Selatan. Fakultas Matematika dan MIPA. Skripsi. Universitan Negeri Gorontalo.

Marsono, D. 1977. Deskripsi Vegetasi dan Tipe-Tipe Vegetasi Tropika. Cetakan Kedua. Bagian Penerbit Yayasan Pembina. Fakultas Kehutanan UGM, Yogyakarta.

Mc Naughton, S. J. dan Wolf, L. L. 1998. Ekologi Umum (Terjemahan). Edisi Kedua. Gadjah Mada University Press.Yogyakarta.

Muller-Dombois, D. dan Ellenberg, H. 1974.Aim and methods of vegetation ecology. (Wiley International ed.). Chichester- New York: John Wiley and Sons.

Nadakuvaren, Mc Cracken. 1985. Studi Tumbuhan Herba di Hutan Sibayak I. Fakultas Matematika dan IImu Pengetahuan Alam Universitas Sumatera Utara, Medan.

Odum, E. P. 1998. Dasar-dasar Ekologi. Edisi Ketiga. Yogyakarta: Universitas Gajah Mada Press.

Rukmana R. 1995. Temulawak: Tanaman Rempah Dan Obat. Jakarta: Kanisius. Halaman 15.

Setiawati S. 2008. Proses Pembelajaran Dalam Pendidikan Kesehatan. Jakarta: Trans Info Media.

Soerianegara I, dan Indrawan A. 1980. Ekologi Hutan Indonesia. Laboratorium PEkologi Hutan. Fakultas Kehutanan. Institut Pertanian Bogor. Bogor

Susanti, A. 2016. Analisis Vegetasi Herba di Kawasan Daerah Aliran Sungai Krueng Jreue Kecamatan Indrapuri Kabupaten Aceh Besar. FakultasTarbiyah dan Keguruan Prodi Pendidikan Biologi. Aceh. 
Indigenous Biologi Jurnal pendidikan dan Sains Biologi

Volume 1(3) 2018

Tropilabinc : bully goad weed http://www.tropilab.com./billy-goad. html diakses pada tanggal 23 Oktober 2012

Zulfikar. 2000. Masyarakat dan ladang. Yogyakarta: Agung Press. BPS// http: www. google. statistik -baumata-kupang. com. 